\title{
NEGÓCIOS JURÍDICOS PROCESSUAIS: OS LIMITES À LIBERDADE DAS PARTES QUANTO AO OBJETO NEGOCIÁVEL NA DINÂMICA PROCESSUAL CIVIL ${ }^{1}$
}

PROCESSUAL LEGAL BUSINESS: THE LIMITS TO THE FREEDOM OF THE PARTIES AS TO THE NEGOTIABLE OBJECT IN CIVIL PROCEDURAL DYNAMICS

Gabriela Taveira RODARTE ${ }^{2}$

Fabiana Maria Martins Gomes de CASTRO ${ }^{3}$

ISSUE DOI: $10.21207 / 2675-0104.2018 .748$

\section{RESUMO}

A presente pesquisa aborda sobre o negócio jurídico processual, temática que ganhou destaque com o advento do Código de Processo Civil de 2015 pela inédita previsão no artigo 190. O instituto compreende a faculdade de as partes ajustarem o procedimento conforme as características singulares da causa, a fim de imprimir eficiência e celeridade na resolução do conflito. O estudo tem como objetivo examinar os princípios basilares, os dispositivos legais correspondentes, as características do

\footnotetext{
${ }^{1} \mathrm{O}$ presente artigo sintetiza a monografia de conclusão da pesquisa, realizada para o Programa Interno de Bolsas de Iniciação Científica (PIBIC 2017-2018) da Faculdade de Direito de Franca (FDF), Franca/SP.

${ }^{2}$ Discente da Faculdade de Direito de Franca (FDF), Franca/SP. Bolsista do Programa Interno de Bolsas de Iniciação Científica (PIBIC 2017-2018).

${ }^{3}$ Doutora em Direito - Efetividade do Direito, subárea Direito Civil pela Pontifícia Universidade Católica de São Paulo (2016). Mestre em Direito das Obrigações pela Universidade Estadual Paulista Júlio de Mesquita Filho - Campus Franca/SP (2003). Graduação em Ciências Sociais e Jurídicas Aplicadas - Faculdades Integradas Toledo Araçatuba (1998). Advogada. Professora Titular da disciplina Direito Civil II na Faculdade de Direito de Franca. Professor de Ensino Superior III-E da Faculdade de Tecnologia de Mococa - Fatec Mococa (desde agosto de 2008) e Diretora da Faculdade de Tecnologia de Mococa (Gestão 2017/2021).
} 
negócio jurídico processual e, sobretudo, os limites formais e objetivos à liberdade das partes. Dessa forma, revela-se a importância da pesquisa para contribuir com os estudos acerca das particularidades dos negócios processuais, sua incidência, requisitos essenciais e limitações. A indagação do estudo é identificar hipóteses de admissibilidade do negócio jurídico processual. A pesquisa foi pautada nos métodos comparativo e dialético, com a utilização do meio de pesquisa bibliográfico. Com o desenvolvimento do estudo, conclui-se que o negócio jurídico processual tem sido utilizado e admitido na jurisprudência, porém reconhece-se que, para atingir a finalidade, sem desvirtuar o instituto, é crucial delinear o acordo com limites razoáveis a atuação das partes, todavia sem obstar a participação dos sujeitos processuais.

Palavras-chave: Negócios Processuais. Limites à liberdade. Objeto negociável.

\section{ABSTRACT}

This research approaches the procedural legal business, theme that gained prominence with the appearance of the Civil Process Code in 2015 for its unprecedented prevision in article 190, which grants the competence to the parties in adjusting the procedure according to particular characteristics of the cause, to imprint efficiency and celerity in the conflict resolution. The study aims at examining the basic tenets, the corresponding legal devices, the main features of procedural le gal business and, above all, the formal and objective boundaries to parties'freedom. These goals reveal the importance of this research to contribute with other studies on procedural business particularities. The research point is to identify hypothesis of admissibility of procedural legal business. It was carried out through the comparative and dialectic methods, based on the bibliographic research method. The development of the study led to the conclusion that the procedural legal business has been used and admitted in the jurisprudence. However, it must be acknowledged that, to reach its goal without being detracted, it is crucial to strike the deal with reasonable boundaries to the performance of the parties, providing that the participation of the procedural subjects will not be hindered.

Keywords: Procedural law. Boundaries to freedom. Negotiable object.

\section{INTRODUÇÃO}

O negócio jurídico processual consiste na oportunidade de as partes adequarem o procedimento conforme a realidade do caso concreto, instituto que está em voga dentre as diversas temáticas contidas no CPC de 2015, devido a sua inédita abordagem expressa e a expectativa de que confira maior eficiência e celeridade na marcha processual.

A atual codificação deixa clara a possibilidade de autorregramento de situações processuais pelos sujeitos de direito material no artigo 190, com a denominada cláusula geral de negociação processual atípica. Porém, o debate surge justamente em torno dos limites à liberdade das partes nessa avença.

Nessa esteira, demonstra-se que a pesquisa será relevante para contribuir na análise da negociação processual, em suas particularidades, classificações, condições essenciais e, principalmente, no tocante às limitações expressas, formais e quanto ao objeto negociável.

Com o presente artigo objetivar-se-á examinar os negócios processuais no ordenamento jurídico brasileiro, através da análise dos 
princípios basilares e dispositivos legais relativos ao tema, em especial, o art. 190, do CPC; refletir acerca dos limites à liberdade das partes no acordo sobre matéria processual e, sobretudo, contribuir com o estudo e evolução desse instituto. Assim, propõe-se como indagação da pesquisa identificar hipóteses de admissibilidade do negócio jurídico processual. Todavia, não há intuito de exaurir o tema.

O primeiro item discorrerá sobre o arcabouço principiológico que norteia o entendimento, a origem e aplicação dos negócios processuais, abrangendo tanto os princípios constitucionais, quanto os infraconstitucionais mais pertinentes ao tema.

No segundo tópico, serão analisados os aspectos teóricos acerca dos fatos, atos e negócios jurídicos; as peculiaridades dos negócios jurídicos processuais, relacionadas a conceito, classificações e posicionamentos doutrinários, bem como será traçado um panorama em sede de direito estrangeiro.

O terceiro item abordará sobre os limites aos negócios processuais, versando sobre os requisitos específicos expressamente previstos no art. 190, do CPC, com os respectivos apontamentos das divergências doutrinárias já suscitadas.

No último tópico, será desenvolvido um estudo de duas hipóteses de objeto negociável, que apresentam discussões acerca da viabilidade. Além disso, o trabalho será arrematado com a análise jurisprudencial envolvendo diversas situações de admissibilidade e outras de inadmissibilidade do negócio jurídico processual.

O estudo será desenvolvido essencialmente por meio de pesquisa bibliográfica, a ser realizada em doutrinas, jurisprudência, periódicos, sites jurídicos, artigos científicos e enunciados interpretativos publicados pelo Fórum Permanente de Processualistas Civis (FPPC).

Para tanto, recorrer-se-á aos métodos comparativo e dialético, haja vista o intuito de analisar os diplomas processuais civis de 1973 e de 2015, o ordenamento jurídico pátrio e o estrangeiro, bem como contrapor as ideias de diversos autores para consecução dos objetivos propostos.

\section{PRINCÍPIOS CORRELATOS AO NEGÓCIO JURÍDICO PROCESSUAL}

No processo civil, assim como nos demais ramos e disciplinas do direito, é essencial a análise dos princípios correlatos para embasar o 
estudo e viabilizar a compreensão efetiva dos institutos, sobretudo, aqueles ainda pouco explorados, como a temática dos negócios processuais.

Assim, é conveniente apontar que, segundo Miguel Reale ${ }^{4}$, os princípios gerais de direito, além de suprirem as lacunas da lei, são os alicerces e vigas mestras do edifício jurídico; por isso, a interpretação e aplicação de modelos jurídicos devem ser realizadas à luz dos princípios. Os juristas e advogados analisam as espécies ocorrentes, em cotejo com os dispositivos legais, fixando diretrizes e formulando pretensões, que conduzem a função jurisdicional.

O sistema processual é informado por princípios básicos de origem constitucional; neste particular, são estudados os princípios do devido processo legal, da inafastabilidade da jurisdição, do juiz natural, da isonomia, do contraditório e da ampla defesa.

Ademais, são analisados princípios infraconstitucionais que norteiam a pesquisa e aplicação do instituto em tela, iniciando-se pelo princípio do respeito ao autorregramento da vontade no processo civil, seguido pelos princípios da boa-fé processual, da cooperação e da adequação.

\subsection{PRINCÍPIOS CONSTITUCIONAIS}

A Constituição Federal de 1988 rege todo o ordenamento jurídico brasileiro, orientando a aplicação e compreensão das normas e institutos infraconstitucionais. Para tanto, precipuamente, elenca diversos princípios, dentre os quais aqueles aplicáveis ao direito processual, que fornecem diretrizes a serem utilizadas na construção e desenrolar do processo, inclusive, isso é exaltado logo no artigo $1^{\circ}$ do CPC. Nesse cenário, não obstante a relevância de outros princípios e considerando-se o objeto do presente estudo, a seguir, são expostos aqueles basilares e mais pertinentes.

O princípio do devido processo legal indica as condições mínimas para o processo desenvolver-se de forma justa, adequada e que seja assegurado às partes o respeito às garantias constitucionais. Deve ser compreendido como aquele que rege toda a atuação jurisdicional do Estado-juiz, sendo inadmissíveis quaisquer restrições na esfera jurídica dos indivíduos sem sua observância.

\footnotetext{
${ }^{4}$ REALE, Miguel. Lições preliminares de direito. 27. ed. São Paulo : Saraiva, 2002. p. 315-316.
} 
O teor do art. $5^{\circ}$, inc. $\mathrm{XXXV}$, da $\mathrm{CF} / 88$, enuncia o princípio da inafastabilidade da jurisdição, do qual decorre o direito de ação. Esse princípio "[...] garante a todos o acesso ao Poder Judiciário, o qual não pode deixar de atender a quem venha a juízo deduzir uma pretensão fundada no direito e pedir solução para ela" ${ }^{5}$. Já os incisos XXXVII e LII, do art. $5^{\circ}$, trazem o princípio do juiz natural, o qual estabelece ser indispensável tanto para uma prestação jurisdicional efetiva quanto para preservar a imparcialidade, que o órgão julgador preexista ao fato e detenha competência para realizar o julgamento.

Nesse contexto, depara-se com os princípios do contraditório e da ampla defesa, expressos no art. $5^{\circ}$, inciso LV, da CF. O contraditório é constituído, sinteticamente, por dois elementos: "informação e reação" ou "ciência e resistência", pois é entendido como o direito de participação de todos os sujeitos processuais envolvidos na demanda. Já a ampla defesa, depreende-se como uma garantia a todo figurante do polo passivo para que tenha condições de responder a tudo o que lhe é imputado.

Assim, é pertinente mencionar o seguinte trecho, no qual Ada Pellegrini Grinover assevera que as partes atuam como colaboradores em relação ao juiz e não como antagonistas:

[...]. Somente pela soma da parcialidade das partes (uma representando a tese e a outra, a antítese) o juiz pode corporificar a síntese, em um processo dialético. Por isso foi dito que as partes, em relação ao juiz, não têm papel de antagonistas, mas sim de "colaboradores necessários" - cada um dos contendores age no processo tendo em vista o próprio interesse, mas a ação combinada dos dois serve à justiça na eliminação do conflito que os envolve (grifos dos autores). ${ }^{6}$

Nota-se que é necessária a observância desses princípios de origem constitucional em âmbito processual, assim, os negócios jurídicos processuais não podem configurar ameaça aos mencionados princípios.

\subsection{PRINCÍPIOS INFRACONSTITUCIONAIS}

O CPC/15 apresenta, nos doze primeiros dispositivos, as normas fundamentais do processo civil, abrangendo os princípios dispositivo, da inércia da jurisdição (art. $2^{\circ}$ ), da inafastabilidade da jurisdição, do direito

\footnotetext{
${ }^{5}$ GRINOVER, Ada Pellegrini et al. Teoria geral do processo. 31. ed. São Paulo: Malheiros Editores, 2015. p. 171

${ }^{6}$ Id., Ibid., p. 79
} 
de ação (art. $3^{\circ}$ ), da celeridade, da duração razoável do processo (art. $4^{\circ}$ ), do dever de boa-fé processual (art. $5^{\circ}$ ), da cooperação (art. $6^{\circ}$ ), da paridade de armas $\left(\operatorname{art.} 7^{\circ}\right.$ ), do contraditório efetivo (arts. $9^{\circ}$ e 10 ), da motivação e publicidade das decisões judiciais (art. 11), dentre outros. Em que pese a relevância de todos, no presente estudo, são desenvolvidos apenas aqueles correlacionados aos negócios jurídicos processuais.

O diploma legal ao contemplar em seu art. 190 a cláusula geral que admite os negócios jurídicos processuais atípicos, expande a liberdade das partes para convencionar sobre os seus ônus, poderes, faculdades e deveres processuais, além da possibilidade de fixarem um calendário processual (art. 191). Além disso, amplia as hipóteses de negócios processuais tipificados ao longo do Código. Nota-se, também, que há maior estímulo à autocomposição das partes. Dentre outros aspectos, os supramencionados demonstram que, em relação ao Código de 1973, houve uma quebra do paradigma publicista no âmbito processual, bem como a redução do protagonismo judicial, cedendo prestígio à liberdade e participação das partes, traços de um processo mais democrático.

Nesse sentido, parcela da doutrina sustenta a consagração de um novo princípio, denominado como princípio do respeito ao autorregramento da vontade das partes no processo, decorrente do direito fundamental à liberdade, já que, no tocante à eficácia desse, encontra-se o direito ao autorregramento que, na visão de Fredie Didier Jr., o seu exercício deve ser garantido, uma vez que "um processo que limite injustificadamente o exercício da liberdade não pode ser considerado devido. Um processo jurisdicional hostil ao exercício da liberdade não é um processo devido, nos termos da Constituição brasileira" (grifos do autor $)^{7}$.

A finalidade desse princípio é criar dentro do processo um âmbito no qual os sujeitos processuais consigam exercer a liberdade, não de maneira ilimitada, porém desde que por limites razoáveis. Assim, na relação com as normas cogentes, o autorregramento tem limites maiores do que no âmbito do direito privado, porém, segundo Pedro H. Pedrosa Nogueira "parece inquestionável a existência de um espaço deixado aos diversos sujeitos processuais, para que possam influir e participar na

\footnotetext{
${ }^{7}$ DIDIER JR., Fredie. Princípio do respeito ao autorregramento da vontade no processo civil. In: CABRAL, Antonio do Passo, e NOGUEIRA, Pedro Henrique (coords.). Coleção grandes temas do novo CPC, v. 1 - negócios processuais. 2. ed. Salvador: JusPodivm, 2016, p. 33.
} 
construção da atividade procedimental, sem que isso represente o reflexo ou a consagração de uma postura "neoprivativista"".

Considerado por diversos autores como uma grande novidade trazida pelo CPC, mesmo que de forma implícita, o princípio ora abordado precisa de um lapso temporal suficiente para ser efetivamente explorado, discutido e difundido entre os operadores do direito.

Consagrado pelo teor do art. $5^{\circ}$, do CPC, o princípio da boa-fé processual refere-se a boa-fé objetivamente considerada, destinada a todo e qualquer sujeito processual, não somente as partes, exigindo que os atos jurídicos sejam desempenhados com lealdade, probidade e de acordo com os padrões éticos de conduta.

Parte da doutrina sustenta que a boa-fé objetiva, no plano processual, comporta três facetas, a saber, "a) standard de comportamento; b) vetor hermenêutico; c) limite ao exercício de posições processuais" ${ }^{9}$. A primeira é identificada pela sinceridade, probidade, eticidade e lealdade esperada na participação dos sujeitos processuais. No vetor hermenêutico, a boa-fé orienta a interpretação dos atos jurídicos e atos processuais. No último campo, está a proibição do venire contra factum proprium e o controle no exercício de posições jurídicas, como ocorre na circunstância prevista pelo art. 190, do CPC, em que o juiz pode controlar a validade dos negócios processuais inseridos de maneira abusiva em contratos de adesão ou quando constatada parte em situação de vulnerabilidade.

A consagração do princípio da cooperação no artigo $6^{\circ}$, do CPC, está relacionada com a valorização da autonomia da vontade no processo. O teor do artigo enuncia o dever de cooperação entre todos os sujeitos envolvidos no processo (autor, réu, juiz, perito etc.). A doutrina constata que o diploma processual civil adota o "modelo cooperativo de processo", não só pela expressa previsão do princípio ora estudado, como também por diversos elementos constantes no CPC. Nesse sentido, Leonardo Carneiro da Cunha explana que se trata de um modelo situado entre o publicista e o garantista, em que o magistrado mantém seus poderes, contudo é necessário "atender aos deveres de cooperação esclarecendo, prevenindo, auxiliando e consultando as partes. O modelo cooperativo diminui o protagonismo do juiz, mas também restringe sua passividade, evitando o

\footnotetext{
${ }^{8}$ NOGUEIRA, Pedro Henrique Pedrosa. Sobre os Acordos de Procedimento no Processo Civil Brasileiro. In: DIDIER JR., Fredie; CABRAL, Antonio do Passo; NOGUEIRA, Pedro Henrique (coords.). Coleção grandes temas do novo CPC, v. 1 - negócios processuais. 2. ed. Salvador: JusPodivm, 2016. p. 96.

${ }^{9}$ GAJARDONI, Fernando da Fonseca. Teoria geral do processo: comentários ao CPC de 2015: parte geral [livro eletrônico]. São Paulo: Forense, 2015. p. 69.
} 
resgate da ideia liberal do processo como uma "luta" ou "guerra" entre as partes" (grifos do autor) ${ }^{10}$.

Cabe destacar que não é pacífico na doutrina a admissibilidade, efetividade e funcionalidade de tal princípio $^{11}$. Assim, apesar do bom propósito do legislador, é precipitado afirmar se, na prática, tal disposição modifica as relações entre os sujeitos processuais.

A doutrina aponta que, mesmo de forma implícita, o princípio da adequação "impõe a exigência de que os procedimentos sejam os mais adequados possíveis (às peculiaridades da causa, às necessidades do direito material, às pessoas dos litigantes, etc.) para que, mediante uma prestação jurisdicional eficiente, a tutela jurisdicional possa ser realmente efetiva" ${ }^{12}$. Nessa seara, Trícia Cabral sustenta que o CPC altera a fisionomia do processo, possibilitando "ser mais maleável e adaptável aos diversos tipos de conflitos sociais levados a juízo, permitindo um tratamento individualizado às demandas" ${ }^{13}$.

Dessa forma, com a adaptabilidade do procedimento, é possível proporcionar o ritmo necessário para a efetiva atuação jurisdicional e o estabelecimento de modificações no procedimento, conforme as especificidades do caso concreto, o que viabiliza o ajuste às características singulares da causa.

\section{A DINÂMICA DO NEGÓCIO JURÍDICO PROCESSUAL}

Feito o estudo do conjunto principiológico que norteia a temática da negociação processual, o artigo científico encaminha-se para as questões específicas dos negócios jurídicos processuais, de modo a, gradativamente, permitir a compreensão e análise das particularidades que delineiam essa modalidade de acordo.

${ }^{10}$ CUNHA, Leonardo Carneiro. Negócios jurídicos processuais no processo civil brasileiro. In: DIDIER JR., Fredie; CABRAL, Antonio do Passo; NOGUEIRA, Pedro Henrique (coords.). Coleção grandes temas do novo CPC, v. 1 - negócios processuais. 2. ed. Salvador: JusPodivm, 2016. p. 59.

${ }^{11}$ NEVES, Daniel Amorim Assumção. Manual de direito processual civil [livro eletrônico]. 8. ed. Salvador: JusPodivm, 2016, vol. único. p. 310.

${ }^{12}$ REDONDO, Bruno Garcia. Negócios processuais: necessidade de rompimento radical com o sistema do CPC/73 para a adequada compreensão da inovação do CPC/2015. In: DIDIER JR., Fredie; CABRAL, Antonio do Passo; NOGUEIRA, Pedro Henrique (coords.). Coleção grandes temas do novo CPC, v. 1 - negócios processuais. 2. ed. Salvador: JusPodivm, 2016. p. 360.

${ }^{13}$ CABRAL, Trícia Navarro Xavier. Reflexos das convenções em matéria processual no atos judiciais. In: CABRAL, Antonio do Passo, e NOGUEIRA, Pedro Henrique (coords.). Coleção grandes temas do novo CPC, v. 1 - negócios processuais. 2. ed. Salvador: JusPodivm, 2016, p. 324. 
3.1 BREVES CONSIDERAÇÕES TEÓRICAS SOBRE FATOS, ATOS E NEGÓCIOS JURIÍDICOS

Inicialmente, cabe esclarecer que os fatos jurídicos lato sensu, subdividem-se em fatos jurídicos lícitos e ilícitos. Dentro dos lícitos, encontram-se o fato jurídico stricto sensu, o ato-fato jurídico e o ato jurídico lato sensu. Este, por sua vez, é ramificado em ato jurídico stricto sensu e negócio jurídico.

Quanto aos fatos jurídicos em sentido amplo, estes são fatos da natureza ou atos humanos. Tratando-se da hipótese de ser ato humano, se inserido em uma estrutura normativa, pode constituir ato jurídico, negócio jurídico, ato ilícito ou ato-fato jurídico. Já no tocante aos fatos naturais, se introduzidos no mundo jurídico, a hipótese é de fatos jurídicos stricto sensu.

Essa classificação ora estudada também existe em âmbito processual. Assim, na visão de Leonardo Carneiro da Cunha, os fatos jurídicos processuais existem e são capazes de produzir efeitos dentro do processo $^{14}$. Em relação ao ato-fato, aquele em que o elemento volitivo é irrelevante. Já os atos processuais em sentido estrito são conceituados por Leonardo Carneiro da Cunha como "manifestações ou declarações de vontade em que a parte não tem qualquer margem de escolha da categoria jurídica ou da estruturação do conteúdo eficacial da respectiva situação jurídica" ${ }^{\prime 15}$.

Isto posto, a análise detalhada acerca dos negócios jurídicos processuais é elaborada nos tópicos subseqüentes.

\subsection{NEGÓCIO JURÍDICO PROCESSUAL: CONCEITO E CLASSIFICAÇÃO}

No tocante ao negócio jurídico processual, cabe expor o conceito elaborado por Pedro Henrique Pedrosa Nogueira: "fato jurídico voluntário em cujo suporte fático esteja conferido ao respectivo sujeito o poder de escolher a categoria jurídica ou estabelecer, dentre dos limites fixados no

${ }^{14}$ CUNHA, Leonardo Carneiro. Negócios jurídicos processuais no processo civil brasileiro. In: DIDIER JR., Fredie; CABRAL, Antonio do Passo; NOGUEIRA, Pedro Henrique (coords.). Coleção grandes temas do novo CPC, v. 1 - negócios processuais. 2. ed. Salvador: JusPodivm, 2016, p. 45.

${ }^{15}$ Id., Ibid., p. 45. 
próprio ordenamento jurídico, certas situações jurídicas processuais" ${ }^{16}$. Já Luiz Rodrigues Wambier e Eduardo Talamini conceituam os negócios jurídicos processuais como "[...] manifestações de vontade que têm por escopo a produção de específicos efeitos processuais, delineados por tais manifestações" ${ }^{17}$.

A doutrina classifica os negócios jurídicos processuais em típicos (expressamente previstos em lei, regulados por dispositivos esparsos e específicos no Código); atípicos ("negócios que não se encaixem nos tipos legais, estruturando-os de modo a atender às suas conveniências e necessidades"18); unilaterais (expressão de vontade de apenas um sujeito) ou bilaterais (acordo elaborado a partir da vontade de dois sujeitos).

Neste ponto, cabe destacar que não é pacífico na doutrina que, ao tempo do CPC de 1973, seria possível falar em atipicidade dos negócios processuais, pois alguns autores apontam que os negócios processuais atípicos ganham mérito é no CPC de 2015, a partir da previsão da cláusula geral de negociação processual no art. 190.

\subsection{POSICIONAMENTO DOUTRINÁRIO PÁTRIO}

Ao tempo da vigência do $\mathrm{CPC} / 73$, a doutrina brasileira não tinha entendimento pacífico acerca da admissibilidade dos negócios jurídicos processuais; muitos autores permaneciam silentes. Outros recusavam, categoricamente, a existência da figura, sob o fundamento de que dentro do processo não haveria cabimento ao autorregramento da vontade. Há, ainda, posicionamento intermediário, pois em razão do artigo 158, do $\mathrm{CPC} / 73$, poderia se admitir o negócio jurídico processual, contando que as negociações das partes necessitariam do pronunciamento judicial para que produzissem os devidos efeitos processuais.

Por outro lado, para a corrente favorável ao reconhecimento dos negócios jurídicos processuais, representada principalmente pelos autores

${ }^{16}$ NOGUEIRA, Pedro Henrique Pedrosa. Sobre os Acordos de Procedimento no Processo Civil Brasileiro. In: DIDIER JR., Fredie; CABRAL, Antonio do Passo; NOGUEIRA, Pedro Henrique (coords.). Coleção grandes temas do novo CPC, v. 1 - negócios processuais. 2. ed. Salvador: JusPodivm, 2016, p. 96.

${ }^{17}$ WAMBIER, Luiz Rodrigues; TALAMINI, Eduardo. Curso avançado de processo civil: teoria geral do processo, v. 1. [livro eletrônico] 5. ed. São Paulo: Revista dos Tribunais, 2016.

${ }_{18}$ CUNHA, Leonardo Carneiro. Negócios jurídicos processuais no processo civil brasileiro. In: DIDIER JR., Fredie; CABRAL, Antonio do Passo; NOGUEIRA, Pedro Henrique (coords.). Coleção grandes temas do novo CPC, v. 1 - negócios processuais. 2. ed. Salvador: JusPodivm, 2016, p. 5657. 
Fredie Didier Jr. e Pedro Henrique Pedrosa Nogueira, encontra-se a argumentação de que a lei traz só a previsão abstrata dos efeitos jurídicos, porém, estes podem ser feitos apenas por meio do acordo de vontades voltado para sua realização ${ }^{19}$.

Com a entrada em vigor do novo diploma processual civil, está pacificada a polêmica sobre a admissibilidade dos negócios jurídicos processuais, face ao disposto pelo artigo 190. Todavia, os autores assinalam diversos pontos ainda controvertidos, que carecem de previsão legal e merecem estudos mais aprofundados.

\subsection{ASPECTOS DE DIREITO ESTRANGEIRO}

Neste ponto, é relevante inserir apontamentos sobre a existência e funcionamento de figuras estrangeiras criadas com intuito de adaptar o procedimento. No direito inglês, depara-se com um instituto denominado case management, ou gestão de caso, implementado devido ao elevado custo da movimentação do judiciário, o que comprometia o acesso à justiça ${ }^{20}$. Na França, são adotados os chamados contrats de procédure, criados com o objetivo remediar a lentidão da justiça francesa. Assim, explana Diogo de Almeida que, a partir de um formato diferente, a França utiliza a flexibilização procedimental para enfrentar as mazelas da justiça ${ }^{21}$. $\mathrm{Na}$ Alemanha, existe a figura dos contratos processuais, inserida após uma reforma processual, dentro de um sistema mais flexível, que permite a

\footnotetext{
${ }^{19}$ Conforme os autores, "todo efeito é, obviamente, consequência da incidência de um enunciado normativo sobre um fato jurídico", mudando-se apenas a liberdade que a norma confere à autonomia privada para a produção dos efeitos jurídicos. Assim, o maior ou menor controle da norma sobre a produção de efeitos não pode descaracterizar o negócio jurídico processual. Quanto à dependência da intervenção judicial para a produção de todo e qualquer efeito do negócio jurídico processual, também se trata de premissa equivocada. Ainda valendo-se da dupla de autores supra, deve-se destacar que o autorregramento da vontade no processo é poder conferido às partes, podendo produzir efeitos independentemente da intervenção do julgador, como no caso da desistência do recurso, que imediatamente produz o efeito de transitar em julgado a decisão recorrida" (MAZZEI, Rodrigo; CHAGAS, Bárbara Seccato Ruis. Os negócios jurídicos processuais e a arbitragem. In: DIDIER JR., Fredie; CABRAL, Antonio do Passo; NOGUEIRA, Pedro Henrique (coords.). Coleção grandes temas do novo CPC, v. 1 - negócios processuais. 2. ed. Salvador: JusPodivm, 2016, p. 662).

${ }^{20}$ CRUZ E TUCCI, José Rogério. Natureza e objeto das convenções processuais. In: DIDIER JR., Fredie; CABRAL, Antonio do Passo; NOGUEIRA, Pedro Henrique (coords.). Coleção grandes temas do novo CPC, v. 1 - negócios processuais. 2. ed. Salvador: JusPodivm, 2016, p. 26.

${ }^{21}$ ALMEIDA, Diogo Assumpção Rezende de. Das convenções processuais no processo civil. 2014. Tese (Doutorado) - Universidade do Estado do Rio de Janeiro. p. 36.
} 
adaptação às características do caso concreto pelas partes ${ }^{22}$. Já na legislação italiana, a reforma processual em 2009 traz diversas alterações no Codice di Procedura Civile com o escopo de atingir maior efetividade e qualidade na justiça, dentre elas a previsão do acordo de procedimento ${ }^{23}$.

De acordo com a pesquisa desenvolvida por Diogo de Almeida, a Noruega, recorre ao modelo inglês para conferir maior eficiência à prestação jurisdicional do país ${ }^{24}$. Acrescenta o citado autor que, em Portugal, objetivando-se concretizar no processo civil o direito fundamental ao acesso à justiça, foram realizadas reformas na legislação, quando se inseriu a possibilidade de adaptação do procedimento ${ }^{25}$. Nessa seara, quanto ao direito argentino, a autor identifica que há a possibilidade do juiz escolher o rito mais adequado e as partes podem celebrar convenção para redução de prazos legais ${ }^{26}$.

Assim, depreende-se que a legislação processual brasileira segue uma tendência mundial de viabilizar maior adequação do procedimento às necessidades do caso concreto, haja vista que modelos semelhantes existem em sistemas jurídicos da common law e da civil law. Pode-se identificar que são diversos os objetivos almejados pelos legisladores estrangeiros com a implementação da figura de acordos de adequação ou flexibilização do procedimento.

Enquanto na Alemanha e em Portugal o intuito é assegurar o acesso à justiça; na Itália e Noruega, objetiva-se maior efetividade e eficiência na prestação jurisdicional; na França, a necessidade é conferir agilidade e qualidade ao processo; e, por fim, na Inglaterra, as finalidades abrangem desde o acesso à justiça e maior eficiência, até a redução de custos e simplificação da linguagem utilizada no processo.

Já no Brasil, a figura dos negócios jurídicos processuais, é introduzida de forma expressa na legislação, por meio do CPC/15, em um atual cenário de crise do sistema de justiça. O referido diploma legal, na tentativa de reparar ou amenizar as mazelas, traz inúmeras novidades, inclusive a cláusula geral de negociação processual atípica, com o propósito de imprimir maior eficiência na prestação jurisdicional e celeridade na marcha processual.

\footnotetext{
${ }^{22}$ CABRAL, Trícia Navarro Xavier. Reflexos das convenções em matéria processual no atos judiciais. In: CABRAL, Antonio do Passo, e NOGUEIRA, Pedro Henrique (coords.). Coleção grandes temas do novo CPC, v. 1 - negócios processuais. 2. ed. Salvador: JusPodivm, 2016, p. 309-310.

${ }^{23}$ Id., Ibid., p. 311.

${ }^{24}$ ALMEIDA, op. cit., p. 46.

${ }^{25}$ Id., Ibid., p. 47-48.

${ }^{26}$ Id., Ibid., p. 53.
} 


\section{LIMITES AOS NEGÓCIOS JURÍDICOS PROCESSUAIS}

Com o desenvolvimento do presente estudo, é possível identificar que o instituto dos negócios jurídicos processuais tem grande potencial de proporcionar mudanças na cultura processual do país. Todavia, conforme pontuado por Marco Paulo Denucci Di Spirito "se o novel instituto é pleno de virtudes, deve ser controlado para que não seja empregado como mecanismo de burla às normas cogentes do ordenamento jurídico" ${ }^{27}$. Para tanto, de modo a coibir eventuais abusividades, os negócios jurídicos processuais devem ser admitidos desde que o processo verse sobre direitos passíveis de autocomposição, com partes capazes e "estejam em situação de equilíbrio, não se permitindo o acordo de procedimento em contratos de adesão ou em contratos em que figurem partes em situação de vulnerabilidade" 28 .

Daniel Amorim Assumpção Neves adverte que a eficácia do acordo independe de homologação judicial, todavia, fica a cargo do magistrado o controle de validade, de ofício ou a requerimento da parte, quanto aos requisitos essenciais ${ }^{29}$.

Assim, demonstra-se a relevância das limitações, que até o momento, a doutrina assinala como o grande dilema a ser enfrentado na aplicação prática dos negócios processuais.

\subsection{REQUISITOS ESPECÍFICOS PREVISTOS NO ART. 190, $\mathrm{CPC} / 15$}

O caput do art. 190, do CPC permite às partes plenamente capazes desde que o processo verse sobre direitos que admitam autocomposição, estipularem mudanças no procedimento com intuito ajustá-lo às especificidades da causa e convencionar sobre os seus ônus, poderes, faculdades e deveres processuais, antes ou durante o processo.

\footnotetext{
${ }^{27}$ DI SPIRITO, Marco Paulo Denucci. Controle de formação e controle de conteúdo do negócio jurídico processual. Revista de Direito Privado, v. 63/2015, p. 125-193, jun./set. 2015. p. 4.

${ }_{28}$ NOGUEIRA, Pedro Henrique Pedrosa. Sobre os Acordos de Procedimento no Processo Civil Brasileiro. In: DIDIER JR., Fredie; CABRAL, Antonio do Passo; NOGUEIRA, Pedro Henrique (coords.). Coleção grandes temas do novo CPC, v. 1 - negócios processuais. 2. ed. Salvador: JusPodivm, 2016. p. 103.

${ }^{29}$ NEVES, Daniel Amorim Assumção. Manual de direito processual civil [livro eletrônico]. 8. ed. Salvador: JusPodivm, 2016, vol. único. p. 588.
} 
Tratando-se de espécie de negócio jurídico, a negociação processual em comento, indubitavelmente se sujeita às condições gerais de validade, previstas no art. 104, do Código Civil. Para tanto, deve conter agente capaz, objeto lícito, possível, determinado ou determinável e forma prescrita ou não defesa em lei. Inclusive, essa é a interpretação que traz o teor do enunciado 403, do Fórum Permanente de Processualistas Civis ${ }^{30}$.

\subsubsection{Capacidade específica das partes}

A capacidade das partes que celebram o negócio jurídico processual é um ponto que suscita divergência doutrinária, porque conforme previsto pelo artigo 190, caput, do CPC, para ser válida a convenção, exige-se que as partes sejam plenamente capazes. Assim, o questionamento recai em considerar tal capacidade como material, processual ou ambas.

A primeira corrente doutrinária entende que se trata de capacidade material, de modo que os absolutamente ou relativamente incapazes, ainda que representados ou assistidos, não podem celebrar negócio jurídico ${ }^{31}$. Essa também é a interpretação registrada no Enunciado 38 da ENFAM $^{32}$, pelo qual, apenas as partes absolutamente capazes podem celebrar convenção pré-processual atípica.

Por outro lado, a segunda corrente doutrinária sustenta que é necessária somente a capacidade processual, de modo que, se os incapazes estiverem processualmente representados podem celebrar o negócio jurídico processual. Para Fredie Didier Jr. ${ }^{33}$ o art. 190, do CPC exige a capacidade processual negocial, isto é, tem como pressuposto a capacidade processual, mas não fica restrita a esta, pois, cite-se como exemplo, no caso da vulnerabilidade tem-se uma incapacidade processual negocial, que não afronta a capacidade processual geral.

\footnotetext{
${ }^{30}$ Enunciado 403 do Fórum Permanente de Processualistas Civis: "A validade do negócio jurídico processual requer agente capaz, objeto licito, possível, determinado ou determinável e forma prescrita ou não defesa em lei".

${ }^{31}$ Nesse sentido: CÂMARA, Alexandre Freitas. O novo processo civil brasileiro. 2. ed. São Paulo: Atlas, 2016. p. 144. GAJARDONI, Fernando da Fonseca. Teoria geral do processo: comentários ao CPC de 2015: parte geral [livro eletrônico]. São Paulo: Forense, 2015.p.1242. YARSHELL, Flávio Luiz. Convenção das partes em matéria processual: rumo a uma nova Era?. In: DIDIER JR., Fredie; CABRAL, Antonio do Passo; NOGUEIRA, Pedro Henrique (coords.). Coleção grandes temas do novo CPC, v. 1 - negócios processuais. 2. ed. Salvador: JusPodivm, 2016. p. 86.

${ }^{32}$ Enunciado 38 da ENFAM: "Somente partes absolutamente capazes podem celebrar convenção préprocessual atípica (arts. 190 e 191 do CPC/2015)".

${ }^{33}$ YARSHELL, Flávio Luiz. Convenção das partes em matéria processual: rumo a uma nova Era?. In: DIDIER JR., Fredie; CABRAL, Antonio do Passo; NOGUEIRA, Pedro Henrique (coords.). Coleção grandes temas do novo CPC, v. 1 - negócios processuais. 2. ed. Salvador: JusPodivm, 2016. p. 384385 .
} 
Ainda, outros autores sustentam que não se pode considerar somente a capacidade processual, pois "se a capacidade for a processual, todo e qualquer sujeito processual poderá celebrar o negócio jurídico ora analisado, já que todos devem ter capacidade de estar em juízo no caso concreto" 34 .

Vale destacar, neste ponto, que a Lei $\mathrm{n}^{\circ} 13.146$, de 6 de julho de 2015 (Estatuto da Pessoa com Deficiência) modificou as disposições relativas à capacidade civil. Logo, atualmente, o artigo $3^{\text {o }}$, do Código Civil, estabelece que são considerados absolutamente incapazes de exercer pessoalmente os atos da vida civil somente os menores de dezesseis anos.

Em contrapartida, o artigo $4^{\circ}$, do Código Civil, prevê que a incapacidade relativa incide nas pessoas maiores de dezesseis e menores de dezoito anos; ébrios habituais e viciados em tóxicos; aqueles que não puderem exprimir sua vontade, devido a alguma causa transitória ou permanente e nos pródigos.

3.1.2 Natureza dos direitos passíveis de negociação

Os negócios jurídicos processuais, conforme previsto no art. 190, do CPC, são admitidos quando o processo versar sobre direitos que admitam a autocomposição.

Com a pesquisa doutrinária, constata-se que é praticamente unânime o entendimento de que a norma foi corretamente elaborada não se confundindo direito indisponível com direito que não admita autocomposição. Isto porque, em processos relativos a direitos indisponíveis é admissível a autocomposição ${ }^{35}$. Essa também é a interpretação anotada no Enunciado 135, do Fórum Permanente de Processualistas Civis, segundo o qual, a indisponibilidade do direito material não impossibilita, por si só, a celebração de negócio jurídico processual. Sendo assim, é necessário investigar a viabilidade de autocomposição.

Nesse cenário, Fernando da Fonseca Gajardoni leciona acerca da análise da natureza autocomponível do direito "Note-se que a análise da natureza autocomponível do direito é feita à luz do direito material sobre o qual versa ou versará o processo, e não sob a ótica exclusivamente

\footnotetext{
${ }^{34}$ NEVES, Daniel Amorim Assumção. Manual de direito processual civil [livro eletrônico]. 8. ed. Salvador: JusPodivm, 2016, vol. único. p. 589

${ }^{35}$ CÂMARA, Alexandre Freitas. O novo processo civil brasileiro. 2. ed. São Paulo: Atlas, 2016. p. 144.
} 
processual (como ocorre com as convenções processuais típicas até então previstas" 36.

Assim, para celebrar um negócio jurídico processual, deve haver observância da natureza autocomponível do direito ao qual o processo refere-se, configurando, desse modo, um dos limites ao campo da convenção.

\subsubsection{IMPOSSIBILIDADE DE INSERÇÃO ABUSIVA EM CONTRATO DE ADESÃO}

O parágrafo único, do art. 190, do CPC, estabelece que o juiz não deve aplicar o negócio processual se ele estiver inserido abusivamente em um contrato de adesão ou quando alguma parte estiver em manifesta situação de vulnerabilidade. Assim, o legislador apresenta uma maneira de vedar possíveis abusos nas convenções processuais e uma preocupação especial com a paridade de armas.

Nesse sentido, Leonardo Carneiro da Cunha adverte que não devem ser afastados todos e quaisquer negócios processuais em sede de contrato de adesão, "em tese, é possível, cabendo apenas ao juiz controlar a validade da respectiva cláusula, recusando-lhe aplicação somente nos casos de nulidade ou de inserção abusiva em contrato de adesão ou no qual alguma parte se encontre em manifesta situação de vulnerabilidade" (grifos do autor) ${ }^{37}$.

Ademais, conforme anotado no Enunciado 408, os integrantes do Fórum Permanente de Processualistas Civis firmam entendimento no sentido de que se houver no contrato de adesão negócio jurídico processual com previsões ambíguas ou contraditórias, dever-se-á adotar a interpretação mais favorável ao aderente. Tal disposição encontra-se também no Código Civil, art. 423.

3.1.4 Situação de manifesta vulnerabilidade de uma das partes

O parágrafo único, do art. 190, do CPC traz uma preocupação especial em assegurar a paridade de armas, ao estabelecer que cabe ao juiz o controle de validade das convenções, sendo necessário recusar aplicação

\footnotetext{
${ }^{36}$ GAJARDONI, Fernando da Fonseca. Teoria geral do processo: comentários ao CPC de 2015: parte geral [livro eletrônico]. São Paulo: Forense, 2015. p. 1241.

${ }_{37}$ CUNHA, Leonardo Carneiro. Negócios jurídicos processuais no processo civil brasileiro. In: DIDIER JR., Fredie; CABRAL, Antonio do Passo; NOGUEIRA, Pedro Henrique (coords.). Coleção grandes temas do novo CPC, v. 1 - negócios processuais. 2. ed. Salvador: JusPodivm, 2016. p. 71.
} 
no caso em que alguma das partes esteja em situação de manifesta vulnerabilidade.

Nessa seara, é pertinente mencionar a seguinte lição de Fredie Didier, que apresenta o conceito e situações que configuram a vulnerabilidade de uma das partes da relação jurídica:

\begin{abstract}
Há vulnerabilidade quando houver desequilíbrio entre os sujeitos na relação jurídica, fazendo com que a negociação não se aperfeiçoe em igualdades de condições. O juridicamente incapaz presume-se vulnerável. Mas há quem seja juridicamente capaz e vulnerável. As posições jurídicas de consumidor e de trabalhador costumam ser apontadas como posições vulneráveis, nada obstante envolvam sujeitos capazes. Nesses casos, a vulnerabilidade precisa ser constatada in concreto: será preciso demonstrar que a vulnerabilidade atingiu a formação do negócio jurídico, desequilibrando-o. Não por acaso o parágrafo único do art.190 diz que o órgão jurisdicional somente reputará nulo o negócio quando se constatar a "manifesta situação de vulnerabilidade" ${ }^{38}$.
\end{abstract}

Assim, é válido esclarecer que "a hipossuficiência deve ser enfocada apenas como vulnerabilidade na sua vertente econômica. A ideia de vulnerabilidade deve girar em torno da concretização dos direitos fundamentais, pois esse é o problema de base" 39 . Ainda, de acordo com Marcos Paulo Di Spirito, o CPC apresenta uma diretriz tutelar em favor da parte mais frágil e o autor traz entendimento do STJ, no sentido de que: "a categoria jurídica dos sujeitos vulneráveis inclui um "subgrupo de sujeitos hipervulneráveis, entre os quais se destacam, por razões óbvias, as pessoas com deficiência física, sensorial ou mental", os indígenas, os idosos, o consumidor idoso, consumidor doente, as crianças consumidoras". ${ }^{40}$

Nesse contexto, o Enunciado n. 18 do Fórum Permanente de Processualistas Civis ${ }^{41}$ é claro quando estipula que se trata de indício de vulnerabilidade quando a parte celebra acordo de procedimento sem assistência técnico-jurídica. Para Fredie Didier Jr., não se trata de presunção de vulnerabilidade, mas sim uma "pista" para ela ${ }^{42}$. Já Daniel Amorim Assumpção Neves sugere que a falta de assistência técnico-

\footnotetext{
${ }^{38}$ DIDIER JR., Fredie. Curso de direito processual civil: introdução ao direito processual civil, parte geral e processo de conhecimento. 17. ed. Salvador: JusPodivm, 2015, vol. I . p. 387.

${ }^{39}$ DI SPIRITO, Marco Paulo Denucci. Controle de formação e controle de conteúdo do negócio jurídico processual. Revista de Direito Privado, v. 63/2015, p. 125-193, jun./set. 2015. p. 31.

${ }^{40}$ Id., Ibid.. p. 19.

${ }^{41}$ Enunciado n. 18 do Fórum Permanente de Processualistas Civis: "Há indício de vulnerabilidade quando a parte celebra acordo de procedimento sem assistência técnico-jurídica”.

${ }^{42}$ DIDIER JR., Fredie. Curso de direito processual civil: introdução ao direito processual civil, parte geral e processo de conhecimento. 17. ed. Salvador: JusPodivm, 2015, vol. I. p. 387
} 
jurídica trata-se de uma presunção relativa de vulnerabilidade, pois "a parte pode não se valer de advogado para celebrar um negócio jurídico processual e ainda assim ter domínio pleno do Direito, como ocorre, por exemplo, com os juízes e promotores de Justiça" ${ }^{43}$.

Nessa seara, depreende-se que é louvável a previsão de controle das disposições abusivas e a proteção especial ao sujeito processual em situação de manifesta vulnerabilidade, de modo a coibir eventuais abusos nas negociações por decorrência de desequilíbrio entre as partes.

\section{$5 \quad$ A DISCUSSÃO EM RELAÇÃO AO OBJETO NEGOCIÁVEL}

Considerando que a cláusula geral de negociação atípica prevista no art. 190, do CPC, possibilita uma ampla gama de hipóteses de acordos processuais que podem ser pensados e propostos pelos sujeitos processuais, fica inviável estabelecer limites peculiares a cada situação.

Contudo, haja vista a necessidade de observância da autonomia da vontade das partes, significativamente ampliada no CPC/15, após todo o estudo, constata-se que a avença não pode contrariar direitos fundamentais, as garantias constitucionais, o devido processo legal e as normas cogentes presentes no ordenamento jurídico brasileiro.

Assim, nesse tópico, o intuito é analisar algumas hipóteses de objeto negociável, sem pretensão de esgotar o tema. Primeiramente, são estudadas a possibilidade de supressão de instância e a legitimação extraordinária negociada. Na sequência, são examinados julgados recentes sobre a matéria, a fim de constatar o posicionamento adotado pelos Tribunais Superiores.

\subsection{ESTUDO DE HIPÓTESES DE OBJETO NEGOCIÁVEL}

No presente subtópico, o artigo científico encaminha-se para análise de duas situações de objeto negociável que têm ocasionado divergência na doutrina e no meio acadêmico, contudo, por ainda não

\footnotetext{
${ }^{43}$ NEVES, Daniel Amorim Assumção. Manual de direito processual civil [livro eletrônico]. 8. ed. Salvador: JusPodivm, 2016, vol. único. p. 595.
} 
possuírem entendimento firmado, precisam de sedimentação jurisprudencial, para efetivação na prática forense.

\subsubsection{A POSSIBILIDADE DE SUPRESSÃO DE INSTÂNCIA}

A supressão de instância como objeto de negociação processual, também abordada como pacto de não-recorribilidade, compreende a situação em que as partes podem estabelecer previamente a avença de não utilizar recursos naquela relação jurídica processual, ou seja, o trâmite do processo fica restrito à primeira instância, tendo um término mais célere, sem a delonga do trâmite recursal. Existem questionamentos se tal objeto pode representar ofensa ao princípio do duplo grau de jurisdição e acarretar prejuízo à parte insatisfeita com a decisão final obtida.

O princípio do duplo grau de jurisdição possui significativa importância para o direito processual e é assentado na possibilidade de a decisão de primeiro grau de jurisdição estar eivada por erro ou injustiça; assim, advém a necessidade de garantir aos jurisdicionados a oportunidade de reforma, por meio da interposição de recurso. Vale salientar que tal princípio não está consagrado expressamente pela Constituição Federal, porém, pela estruturação do Poder Judiciário e pela competência distribuída aos tribunais, depreende-se que o texto constitucional traz implicitamente o duplo grau de jurisdição, não o prevendo como uma garantia.

Nessa seara, Paulo Mendes de Oliveira sustenta que é possível as partes renunciarem livremente o direito ao recurso, conformando-se com a decisão de primeiro grau, apta a forma coisa julgada material, isto porque, "não há inconstitucionalidade na supressão, por ato legislativo, do duplo grau de jurisdição. Disso decorre que a possibilidade de revisão da decisão por um tribunal não integra o iter necessário ao cumprimento pelo Estado do seu dever de prestar a jurisdição" ${ }^{4}$.

Por outro lado, o mesmo autor identifica argumentos contrários: "a renúncia antecipada ao direito de recorrer sempre foi vista com reservas pela doutrina, justamente pela impossibilidade de se abrir mão de um

\footnotetext{
${ }^{44}$ OLIVEIRA, Paulo Mendes de. Negócios processuais e o duplo grau de jurisdição. In: DIDIER JR., Fredie; CABRAL, Antonio do Passo; NOGUEIRA, Pedro Henrique (coords.). Coleção grandes temas do novo CPC, v. 1 - negócios processuais. 2. ed. Salvador: JusPodivm, 2016. p. 575.
} 
direito que sequer existe. As partes estariam assumindo um risco antecipado" ${ }^{45}$.

Daniel Amorim Assumpção Neves também expressa seu ponto de vista favorável: "o direito recursal é reconhecidamente fundado nos princípios do contraditório e da ampla defesa, mas a doutrina parece tranquila em admitir no negócio jurídico processual que verse sobre a renúncia do direito recursal" ${ }^{46}$.

Cabe destacar, nesse ponto, o que aduzem Júlia Lipiani e Marília Siqueira acerca da admissibilidade sobre renúncia recursal:

[...] em primeiro lugar, se o recurso é remédio voluntário, e não compulsório, não há porque negar-lhe a possibilidade de renúncia antecipada, inclusive por ambas as partes, em conjunto, de forma negociada. Em segundo lugar, se ninguém é obrigado a demandar, também não pode ser obrigado a recorrer, de modo a prolongar o seu direito de ação. E, em terceiro lugar, se o direito de recorrer trata-se de direito potestativo, não há razões para que se impeça que as partes, isolada ou conjuntamente, abram mão de tal direito. ${ }^{47}$

As citadas autoras pontuam, ainda, que em tal hipótese de negociação, merecem um cuidado especial os embargos de declaração, pois "apesar de ser possível a negociação de sua renúncia, ressalvou-se o entendimento de que é conveniente que se evite negócio com este objeto, a fim de se possibilitar o aperfeiçoamento e a integração de cada decisão" 48.

Nessa esteira, constata-se que diversos estudiosos já se dedicaram à averiguação da possibilidade de se convencionar a supressão da instância recursal. Assim, muito embora alguns operadores do direito ainda não tenham reconhecido tal objeto de negociação, por meio desse estudo, demonstra-se que é plenamente viável a convenção processual tratar sobre renúncia bilateral ao direito de recorrer, antes ou durante o curso processual, a fim de que as partes obtenham uma solução mais célere, sem enfrentar a morosidade do trâmite recursal.

\footnotetext{
${ }^{45}$ Id., Ibid., p. 575.

${ }^{46}$ NEVES, Daniel Amorim Assumção. Manual de direito processual civil [livro eletrônico]. 8. ed. Salvador: JusPodivm, 2016, vol. único. p. 598.

${ }^{47}$ LIPIANI, Júlia; SIQUEIRA, Marília. Negócios jurídicos processuais sobre a fase recursal. In: DIDIER JR., Fredie; CABRAL, Antonio do Passo; NOGUEIRA, Pedro Henrique (coords.). Coleção grandes temas do novo CPC, v. 1 - negócios processuais. 2. ed. Salvador: JusPodivm, 2016. p. 602 ${ }^{48}$ Id., Ibid., p. 612.
} 


\subsubsection{A LEGITIMAÇÃO EXTRAORDINÁRIA}

A legitimidade ad causam é a condição ostentada por aquele sujeito que tem poder de figurar no polo processual (ativo ou passivo). De acordo com a doutrina, tal legitimidade pode ser subdividida em ordinária ou extraordinária.

De forma que, se coincidem as partes de direito material e de direito processual, trata-se de legitimidade ordinária, ou seja, a pessoa defende o próprio interesse, por meio de seu próprio nome. Contudo, excepcionalmente, mediante autorização do ordenamento jurídico, admitese a legitimação extraordinária, que ocorre na hipótese em que não coincidem os sujeitos processuais com os sujeitos da relação jurídica material; nesse caso, a pessoa com legitimidade extraordinária atua em juízo em nome próprio, por interesse de outro sujeito.

Fredie Didier Jr. leciona que, sob a égide do CPC de 1973, entendia-se que era inviável a legitimação extraordinária negocial, pois "por um negócio jurídico, não se poderia atribuir a alguém a legitimação para defender interesses de outrem em juízo. Isso porque o art. $6^{\circ}$ do CPC/1973 reputa a lei, e apenas ela, a fonte normativa de legitimação extraordinária" ${ }^{49}$.

Em sede de CPC de 2015, o artigo 18 prevê que ninguém pode pleitear direito alheio em nome próprio, salvo quando autorizado pelo ordenamento jurídico, assim, o dispositivo deve ser interpretado em conjunto com a nova sistemática processual, inclusive, observando-se a implantação da cláusula geral de negociação processual atípica (art. 190).

Dessa forma, Fredie Didier Jr. evidencia a possibilidade desse objeto negociável:

Negócio jurídico é fonte de norma jurídica, que, por isso mesmo, também compõe o ordenamento jurídico. Negócio jurídico pode ser fonte normativa da legitimação extraordinária. Este negócio jurídico é processual, pois atribui a alguém o poder de conduzir validamente um processo. Não há, assim, qualquer obstáculo $a$ priori para a legitimação extraordinária de origem negocial. E, assim sendo, o direito processual civil brasileiro passará a permitir

\footnotetext{
${ }^{49}$ DIDIER JR., Fredie. Fonte normativa da legitimação extraordinária no novo Código de Processo Civil: a legitimação extraordinária de origem negocial. Revista de Processo, São Paulo, RT, ano 39, v. 232, p. 69-76, jun. 2014. Disponível em: <https://www.academia.edu/36514448/Fonte normativa_da_legitima\%C3\%A7\%C3\%A3o_extraordi n\%C3\%A1ria no Novo C\%C3\%B3digo de Processo Civil a legitima\%C3\%A7\%C3\%A3o extra ordin\%C3\%A1ria de origem negocial>. Acesso em: 29 maio 2018. p. 71.
} 
a legitimação extraordinária atípica, de origem negocial (grifos do autor). ${ }^{50}$

Assim, Daniela Santos Bomfim indica uma conclusão lógica acerca da viabilidade de se convencionar sobre a legitimação extraordinária:

\begin{abstract}
A cláusula geral prevista, em sua abertura semântica, apreende a legitimidade extraordinária negocial, que não é vedada em nenhuma norma do sistema. Ora, se $o$ art. 18 possibilita a irradiação da legitimidade extraordinária, desde que autorizada pelo sistema jurídico, se o art. 190 é justamente a autorização do sistema, o espaço deixado ao autorregramento, e se não há qualquer norma do sistema que proíba o exercício do autorregramento autorizado, a conclusão é lógica: o sistema jurídico autoriza o exercício do autorregramento para a escolha da categoria eficacial no que concerne à legitimidade ad causam. ${ }^{51}$
\end{abstract}

Cabe destacar, ainda, o entendimento registrado por Daniel Amorim Assumção Neves, também favorável à admissibilidade da legitimação extraordinária convencional: "apesar de ser matéria de ordem pública, não vejo nesse momento obstáculos para a admissão da legitimação extraordinária convencional porque a vontade dessas partes não traz qualquer prejuízo ou oneração ao Poder Judiciário" 52.

Nesse contexto, Fredie Didier Jr. assevera que se deve considerar a diferença na solução, conforme se tratar de legitimação extraordinária ativa ou passiva. A primeira "não exige outro requisito, além dos exigidos para os negócios processuais em geral" "53. Já a passiva, o autor explana que demanda concordância do titular do polo ativo" 54 .

Logo, diante de todo o exposto, extrai-se que a doutrina tem admitido a celebração de acordos processuais para negociar legitimação extraordinária em uma relação jurídica processual, o que revela uma

\footnotetext{
${ }^{50}$ Id., Ibid., p. 72.

${ }^{51}$ BOMFIM, Daniela Santos. A legitimidade extraordinária de origem negocial. In: CABRAL, Antonio do Passo, e NOGUEIRA, Pedro Henrique (coords.). Coleção grandes temas do novo CPC, v. 1 negócios processuais. 2. ed. Salvador: JusPodivm, 2016. p. 460.

${ }^{52}$ NEVES, Daniel Amorim Assumção. Manual de direito processual civil [livro eletrônico]. 8. ed. Salvador: JusPodivm, 2016, vol. único. p. 602.

${ }^{53}$ DIDIER JR., Fredie. Fonte normativa da legitimação extraordinária no novo Código de Processo Civil: a legitimação extraordinária de origem negocial. Revista de Processo, São Paulo, RT, ano 39, v. 232, p. 69-76, jun. 2014. Disponível em: <https://www.academia.edu/36514448/Fonte normativa_da legitima\%C3\%A7\%C3\%A3o_extraordi n\%C3\%A1ria no_Novo_C\%C3\%B3digo_de Processo_Civil_a legitima\%C3\%A7\%C3\%A3o extra ordin\%C3\%A1ria de origem negocial>. Acesso em: 29 maio 2018. p. 72.

${ }^{54}$ Id., Ibid., p. 72.
} 
significativa evolução da sistemática processual ao valorizar o autorregramento das partes, comparando-se com o ideário mantido durante a vigência do diploma processual anterior.

\subsection{POSICIONAMENTO DOS TRIBUNAIS SUPERIORES}

Nesse ponto, o artigo científico segue para o estudo do posicionamento dos Tribunais Superiores exarado em julgados recentes, de modo a analisar e demonstrar como o negócio jurídico processual tem sido empregado na prática forense. Para viabilizar uma organização lógica, os julgados selecionados são agrupados conforme admissibilidade ou inadmissibilidade do negócio jurídico processual apresentado em cada situação concreta.

\subsubsection{SITUAÇÕES DE INADMISSIBILIDADE DO NEGÓCIO JURÍDICO PROCESSUAL}

Primeiramente, a proposta é analisar o posicionamento do Tribunal de Justiça de São Paulo exarado em um julgado, no qual o negócio jurídico processual celebrado entre as partes é considerado inadmissível ${ }^{55}$. Refere-se ao julgamento de Agravo de Instrumento interposto contra decisão que indeferiu a tutela antecipada pretendida em ação de despejo ajuizada. Conforme as razões recursais, não houve observância do julgador quanto à convenção processual firmada entre as partes. Pois, em sede de contrato de locação, desprovido de qualquer garantia, locador e locatário acordaram em uma cláusula expressa que o não pagamento dos alugueis autorizaria a desocupação imediata, liminarmente à ação de despejo.

Ocorre que, o art. 59, $\S 1^{\circ}$, inc. IX da Lei n. ${ }^{\circ} 8.245 / 91$ (Lei de Locações) exige caução para concessão de liminar nesses casos, porém, o locador não prestou caução, sustentando que o negócio jurídico processual celebrado afasta tal exigência.

Dessa forma, a Relatora Desembargadora Maria Lúcia Pizzotti, no voto trabalha com a ideia de que o acordo processual realizado nos autos não contempla uma autêntica autonomia da vontade das partes. $\mathrm{Na}$

\footnotetext{
${ }^{55}$ TJSP, Agravo de Instrumento n. ${ }^{\circ} 22334788820178260000,30 .^{\text {a }}$ Câmara de Direito Privado, Relatora Maria Lúcia Pizzotti, Julgamento: 21/03/2018, Publicação: 26/03/2018.
} 
sequência, desenvolve a percepção de que a negociação elaborada nos autos representa uma ofensa ao dever de boa-fé, consoante o seguinte fragmento: "uma vez afastada a obrigação de prestar caução para fins de desocupação liminar, há ofensa ao dever de boa-fé, afinal, o locador não poderia ter qualquer "certeza" de que seu pedido será integralmente acolhido" 56.

Logo, após análise do inteiro teor do acórdão, constata-se que o Egrégio Tribunal de Justiça do Estado de São Paulo nega provimento ao recurso, por unanimidade, mantendo a decisão do juízo de origem, a qual inadmitiu a negociação processual que previa o afastamento da obrigação de prestar caução para fins de desocupação liminar.

Em suma, a fundamentação dos desembargadores baseia-se na possibilidade de o magistrado controlar a validade do negócio jurídico processual, na hipótese de inserção abusiva em contrato de adesão ou quando alguma parte se encontre em situação de vulnerabilidade (art. 190, parágrafo único), o que é verificado no contexto do julgado. Além disso, destaca-se que não houve respeito ao dever de boa-fé, inclusive com menção ao Enunciado 06 do Fórum Permanente de Processualistas Civis, cujo teor prevê que "o negócio jurídico processual não pode afastar os deveres inerentes à boa-fé e à cooperação."

O próximo julgado a ser analisado trata-se de um Agravo de Instrumento interposto contra decisão que, nos autos de ação indenizatória, indeferiu pedido de denunciação da lide à seguradora contratada pela empresa ré em relação ao veículo envolvido no acidente automobilístico ${ }^{57}$.

A parte recorrente alega a necessidade de observância ao negócio jurídico processual celebrado com a parte adversa, pois foi firmado o valor indenizatório em $\mathrm{R} \$ 50.000,00$, com a condição de que, na hipótese de rejeição do sinistro pela seguradora, fosse ela denunciada à lide. Ademais, aponta que o juiz não indeferiu ou fez qualquer ressalva quanto aos termos do negócio processual. Inclusive, determinou a suspensão do feito até o encerramento em âmbito administrativo; dessa forma, a decisão agravada representou ofensa ao artigo 10, do CPC, que proíbe a decisão surpresa. Assim, requer que, com o provimento do recurso haja ampliação do polo passivo.

Nesse contexto, vale transcrever o seguinte trecho do voto formulado pelo Relator Desembargador Walter Cesar Exner:

\footnotetext{
${ }^{56}$ Id., Ibid.

${ }^{57}$ TJSP, Agravo de Instrumento $\mathrm{n}^{\circ}$ 2161535-45.2016.8.26.0000, 36. ${ }^{\mathrm{a}}$ Câmara de Direito Privado, Relator Walter Cesar Exner, Julgamento: 19/09/2016, Publicação: 19/09/2016.
} 
[...] o que pretende a agravante é a ampliação dos limites subjetivos da lide, vedada pelo disposto no art. 329 do mesmo diploma legal, sobretudo porque já regularmente saneado o processo. Cumpre ainda observar que o negócio jurídico processual previsto no art. 190 do CPC/15 não pode suprimir direito de defesa, do contraditório, ou eliminar quaisquer garantias constitucionais, muito menos de terceiros estranhos ao processo, como o que se pretende com a denunciação da lide à seguradora quando já saneado o feito, considerando-se ainda que sequer foi colacionado aos autos qualquer contrato em que haja indicação de eventual obrigação da seguradora, que, de acordo com documento juntado pela parte, recusou-se a pagar a indenização pretendida, porque não contratado cobertura para dano moral (grifo nosso). ${ }^{58}$

No acórdão, a tese de que houve decisão surpresa é afastada, de plano, pelo Desembargador Relator, pois a decisão agravada esclarece que houve suspensão do processo por trinta dias para acolher pedido das partes, para finalização do procedimento administrativo objetivando pagamento de eventual seguro em favor da autora e esse sobrestamento não implicou em homologação do negócio jurídico processual.

Logo, a decisão agravada é mantida integralmente e ao recurso é negado provimento, por unanimidade dos votos.

Como restou evidenciado, o Tribunal de Justiça do Estado de São Paulo entende que, na hipótese, as partes utilizando o negócio jurídico processual objetivavam ampliar os limites subjetivos da lide após o saneamento do feito, o que não pode ser realizado, por disposição do artigo 329, do CPC; bem como é um objeto inviável para a negociação, haja vista que é inadmissível em casos prejudiciais ao direito de defesa, ao contraditório, ou quaisquer garantias constitucionais, muito menos de terceiros estranhos ao processo.

4.2.2 Situações de admissibilidade do negócio jurídico processual

A análise a seguir refere-se ao julgado de Agravo de Instrumento interposto contra decisão que, nos autos de ação monitória em fase de cumprimento de sentença, determinou a intimação da devedora, pessoalmente, para pagamento do débito, sob pena de multa correspondente a $10 \%$ sobre o valor do débito, nos termos do art. 475-J do $\mathrm{CPC} / 1973^{59}$.

A agravante alega que, em negócio jurídico processual celebrado entre as partes, foi pactuada a forma de realização de eventuais intimações,

\footnotetext{
${ }^{58}$ Id., Ibid.

59 TJSP, Agravo de Instrumento $\mathrm{n}^{\circ}$ 2045753-87.2016.8.26.0000, 32. ${ }^{\mathrm{a}}$ Câmara de Direito Privado, Relator Luis Fernando Nishi, Julgamento: 22/09/2016, Publicação: 22/09/2016.
} 
podendo ser recebidas por qualquer terceiro que se encontre no endereço declinado.

No mais, afirma que, como o referido acordo foi devidamente homologado, assim, a intimação pessoal da executada (determinada na decisão agravada) torna-se desnecessária, devendo ser afastada a justificativa de ausência de patrono constituído pela agravada nos autos e que a intimação seja feita dos moldes do pactuado.

É pertinente mencionar o seguinte trecho do voto elaborado pelo Relator Desembargador Luis Fernando Nishi:

Considerando as peculiaridades do caso concreto, desnecessário a intimação pessoal, devendo prevalecer o convencionado em contrato (cláusula primeira, cf. fls. 40), ou seja, as intimações devem ser realizadas no endereço declinado no acordo pactuado, ficando autorizado o recebimento de intimação por quaisquer terceiros que se encontrem. [...] Consagrado na nova ordem processual, o CPC/2015 permite o negócio jurídico processual, como fundamento no dever de colaboração, face aos interesses disponíveis dos envolvidos, como forma, ainda, da efetividade da prestação jurisdicional, certo, ademais, que a disposição em análise decorre de acordo entra as partes, agora em fase de cumprimento, sem que nisso resida qualquer violação de lei (grifo nosso). ${ }^{60}$

Portanto, conforme se infere do acórdão, o negócio jurídico processual é plenamente admitido por cumprir seus requisitos essenciais e não incorrer em qualquer violação à lei. O Desembargador Relator destaca, ainda, que a negociação tem como fundamento o dever de colaboração das partes na marcha processual. Dessa forma, por unanimidade é dado provimento ao recurso de Agravo de Instrumento.

O julgado objeto de estudo a seguir refere-se a um Agravo de Instrumento interposto contra decisão que, nos autos da execução de título executivo extrajudicial, indeferiu o pedido de penhora de imóveis prevista no acordo entabulado entre as partes. A ementa traz o seguinte teor:

EXECUÇÃO DE TÍTULO EXECUTIVO EXTRAJUDICIAL Acordo levado a efeito entre as partes, com previsão de penhora sobre imóveis oferecidos pelos executados Viabilidade - Com o advento do novo CPC, é possível as partes celebrarem negócio jurídico processual, amoldando as normas processuais de acordo com os seus interesses Inteligência do art. 190 do CPC/2015 Composição que preserva os interesses das partes, bem como

${ }^{60}$ Id., Ibid. 
encontra arrimo no artigo 774 , inciso $\mathrm{V}$, e art. $829, \S 2^{\circ}$, do CPC/2015 - Decisão reformada - Recurso provido. ${ }^{61}$

No relatório do acórdão, foi copiada a r. decisão agravada, na qual o juiz de primeiro grau expõe que: "o pedido de lavratura de termo de penhora mascara verdadeira hipoteca celebrada entre as partes sem a concorrência do Juízo. Assim, deverão, para cumprir o acordo particular, celebrar hipoteca que é a garantia própria realizada entre particulares" 62 .

Diante disso, a parte agravante alega, em suma, que a mencionada decisão viola as determinações de que a execução deve ser conduzida de acordo com o interesse do exequente e da maneira menos onerosa ao executado (arts. 797 e 805, do CPC). Além disso, sustenta a possibilidade de celebração de negócio jurídico processual e que é inviável mascarar uma hipoteca por meio de penhora, haja vista que os efeitos oriundos dos institutos são diferentes.

Acontece que, nos autos da execução, as partes firmaram acordo para reconhecimento e parcelamento da dívida; no mais, os agravantes, para garantir o adimplemento, ofereceram imóveis à penhora e direitos sobre imóveis gravados com hipoteca e alienação fiduciária.

Dessa forma, a agravante pleiteia a homologação do ajuste firmado entre as partes, com o deferimento da penhora dos imóveis, bem como a expedição do termo de penhora e registro nas respectivas matrículas, até que haja o integral cumprimento do acordo. Tal pedido, conta, inclusive, com a concordância dos agravados.

No voto, o Relator Desembargador Paulo Pastore Filho identifica que o magistrado de primeiro grau: "entendeu pela impossibilidade da penhora dos imóveis conforme acordo celebrado entre as partes, uma vez que seria necessária a lavratura de escritura pública para constituição de garantia de hipoteca. Respeitado tal posicionamento, assim não pode ser"63. Na sequência, demonstra que a avença é admissível:

O fato de os agravados oferecerem imóveis à penhora, com a concordância da empresa exequente, por meio de acordo celebrado entre as partes, não se revela uma convenção incompatível com os princípios e garantias constitucionais, tampouco enseja desvirtuamento da ordem pública processual. Na hipótese, a composição sobre a penhora de bens preserva os interesses das

\footnotetext{
${ }^{61}$ TJSP, Agravo de Instrumento n. ${ }^{\circ}$ 2118535-58.2017.8.26.0000, 17. ${ }^{a}$ Câmara de Direito Privado, Relator Paulo Pastore Filho, Julgamento: 30/11/2017, Publicação: 30/11/2017.

${ }^{62}$ Id., Ibid.

${ }^{63}$ TJSP, Agravo de Instrumento n. ${ }^{\circ}$ 2118535-58.2017.8.26.0000, 17. a Câmara de Direito Privado, Relator Paulo Pastore Filho, Julgamento: 30/11/2017, Publicação: 30/11/2017.
} 
partes, bem como encontra arrimo no artigo 774, inciso V, e art. $829, \S 2^{\circ}$, do CPC/2015 (grifo nosso). ${ }^{64}$

Ainda, o Relator pondera que o acordo merece observância por sobrelevar a duração razoável do processo, a celeridade e economia da prestação jurisdicional $^{65}$. Ao final, assevera que, quanto às demais disposições inseridas pelas partes no acordo, cabe ao MM. Juiz da causa "efetuar análise prévia à chancela, a fim de se evitar eventual nulidade ou inserção abusiva, assegurando-se, ainda, a salvaguarda de eventuais direitos de terceiros." 66

Dessa forma, por unanimidade, os Desembargadores dão provimento ao recurso de Agravo de Instrumento, reconhecendo a admissibilidade do negócio jurídico processual na forma como foi entabulado pelas as partes. Portanto, depreende-se que, na situação concreta apresentada, o negócio jurídico processual é plenamente válido e impõe observância aos termos ajustados por todos os sujeitos envolvidos no curso do processo.

\section{CONSIDERAÇÕES FINAIS}

Esta pesquisa buscou, ao tratar da temática dos negócios jurídicos processuais, analisar a faculdade de as partes ajustarem o procedimento conforme as características singulares da causa. Assim, inicialmente, foi constatado que, devem ser observadas as premissas fundamentais constitucionalmente previstas, de modo que a negociação entre as partes sobre matéria processual não pode afrontar os princípios basilares como o do devido processo legal, da inafastabilidade da jurisdição, do juiz natural, da isonomia, do contraditório e da ampla defesa.

No mais, percebeu-se que o CPC/15 inovou ao valorizar a participação das partes na condução da marcha processual, estabelecendo de forma expressa o princípio da cooperação, bem como, por decorrência de interpretação doutrinária, viabilizou a eclosão dos princípios da

\footnotetext{
${ }^{64}$ Id., Ibid.

65 " [...] a não realização da penhora, tal como pretendida pelas partes, obstruiria a finalidade precípua da execução de expropriar bens do executado para a satisfação do direito do exequente, inviabilizando a celeridade e economia da prestação jurisdicional, e desestimulando a conciliação. Portanto, não há se falar em óbice ao deferimento da penhora de imóveis, previsto em acordo celebrado entre as partes nos autos da execução" (TJSP, Agravo de Instrumento n. ${ }^{\circ}$ 2118535-58.2017.8.26.0000, 17. ${ }^{\text {a Câmara de }}$ Direito Privado, Relator Paulo Pastore Filho, Julgamento: 30/11/2017, Publicação: 30/11/2017).

${ }^{66}$ Id., Ibid.
} 
adequação e do respeito ao autorregramento da vontade. Denotou-se, então, que o diploma processual civil intenta abrandar a rigidez do procedimento e o enfoque no juiz como único protagonista do processo.

Ao analisar estudos específicos do direito estrangeiro, depreendeu-se que o CPC/15 aderiu a uma tendência mundial de viabilizar maior adequação do procedimento às necessidades do caso concreto, haja vista a existência de figuras semelhantes em sistemas jurídicos da common law e da civil law.

Identificou-se que vários países implantaram institutos para flexibilização do procedimento, visando atender diversos objetivos. Assim, na Alemanha e em Portugal o intuito foi assegurar o direito ao acesso à justiça; na Itália e Noruega, objetivou-se maior efetividade e eficiência na prestação jurisdicional; na França, a necessidade era conferir agilidade e qualidade ao processo; e, por fim, na Inglaterra, as finalidades abrangem desde o acesso à justiça e maior eficiência, até a redução de custos e simplificação da linguagem utilizada no processo.

Já na legislação brasileira, a figura dos negócios jurídicos processuais foi introduzida de maneira expressa no $\mathrm{CPC} / 15$, em um cenário de crise do sistema de justiça. Esse diploma legal, a fim de atenuar as mazelas, trouxe diversas inovações, inclusive a cláusula geral de negociação processual atípica, com o propósito de imprimir maior eficiência na prestação jurisdicional e celeridade na marcha processual.

Em seguida, concluiu-se que diante de uma gama de hipóteses autorizadoras à celebração de negócios jurídicos processuais, é inegável a existência e admissibilidade do referido pacto na atual codificação e a viabilidade de ser consolidado na prática forense.

Constatou-se a importância de delinear os limites formais e objetivos, visando coibir eventuais práticas abusivas, o que a doutrina aponta como grande dilema a ser enfrentado. Assim, além dos requisitos gerais para elaboração de negócios jurídicos, para ser admitida, a negociação processual deve respeitar os requisitos especificados no artigo 190, do CPC e abarcar objeto material, isto é, o conteúdo inserido no acordo, compatível com o ordenamento jurídico brasileiro.

Contudo, considerando a necessidade de observância da autonomia da vontade das partes, significativamente ampliada no CPC/15, notou-se que a avença não pode contrariar direitos fundamentais, as garantias constitucionais, o devido processo legal e as normas cogentes presentes no ordenamento jurídico brasileiro. 
Além disso, ao examinar particularmente o objeto negociável, concluiu-se que, apesar de ainda não ser amplamente aceito pelos operadores do Direito, é admissível o acordo processual que trate sobre renúncia bilateral do direito de recorrer, antes ou durante o curso processual, com intuito de que as partes obtenham uma solução mais célere, sem enfrentar a morosidade do processo na via recursal.

Ainda, verificou-se que a doutrina tem admitido a legitimação extraordinária como objeto negociável em uma relação jurídica processual, revelando um progresso da sistemática processual ao valorizar o autorregramento das partes, o que não se encontrava sob a égide do diploma processual anterior.

Durante a análise jurisprudencial foi possível constatar que o negócio jurídico processual tem sido adotado pelas partes, inserindo-o em cláusula contratual, utilizando-o durante o processo para simplificar diligências como a intimação, convencionar sobre a realização de nova audiência e oferecer imóveis à penhora.

Nessas situações, os Tribunais Superiores admitiram as negociações, em síntese, com fundamentação de se priorizar a celeridade, efetividade e economia da prestação jurisdicional, estimular a conciliação e dever de colaboração. A admissibilidade sempre com prévia análise de compatibilidade com os princípios e garantias constitucionais, sem violação de lei e da ordem pública processual.

Por outro lado, verificou-se que em algumas hipóteses o negócio jurídico processual foi invalidado por não ser fruto de autonomia de vontades, mas sim instrumento para afastar lei específica desfavorável a uma das partes; por representar ofensa ao dever de boa-fé; por suprimir direito de defesa, do contraditório ou eliminar quaisquer garantias constitucionais.

Dada a importância das restrições, não é razoável arguir que a liberdade das partes pode exceder os limites expressos, quais sejam, capacidade plena das partes, versar sobre direitos que admitam autocomposição, impossibilidade de inserção abusiva em contrato de adesão ou em que alguma parte se encontre em manifesta situação de vulnerabilidade; e sequer extrapolar ordenamento, mediante objeto incompatível. O instituto foi implantado para a condução da marcha processual conforme as características singulares do caso concreto, facilitando, assim, a resolução do litígio; e não para oportunizar práticas repudiáveis na legislação vigente. 
Assim, uma vez preenchidos os pressupostos estabelecidos pelo artigo 190 e observados os ditames legais vigentes, o negócio jurídico processual deve ser admitido e respeitado pelo juiz da causa, bem como cumprido por todos os sujeitos que nele figurarem.

Por fim, sob um panorama de toda a extensão da pesquisa, os objetivos propostos inicialmente foram alcançados satisfatoriamente, considerando que se analisou o contexto no qual os negócios jurídicos processuais foram inseridos, os princípios mais pertinentes ao tema, os dispositivos legais correspondentes e os limites estabelecidos. Além disso, foram examinadas hipóteses de objeto negociável reconhecidas pela maior parte da doutrina; julgados nos quais se admitiu o negócio jurídico processual e outros em que foi necessário o controle judicial para afastar a convenção inadequada ou eivada por abusividades.

\section{REFERÊNCIAS BIBLIOGRÁFICAS}

ALMEIDA, Diogo Assumpção Rezende de. Das convenções processuais no processo civil. 2014. Tese (Doutorado) - Universidade do Estado do Rio de Janeiro.

BRASIL. Enunciados do Fórum Permanente de Processualistas Civis. Disponível em: <https://institutodc.com.br/wp-content/uploads/2017/06/FPPC-Carta-de-Florianopolis.pdf>. Acesso em: 11 mar. 2018.

BOMFIM, Daniela Santos. A legitimidade extraordinária de origem negocial. In: CABRAL, Antonio do Passo, e NOGUEIRA, Pedro Henrique (coords.). Coleção grandes temas do novo CPC, v. 1 negócios processuais. 2. ed. Salvador: JusPodivm, 2016, p. 447-464.

CABRAL, Trícia Navarro Xavier. Reflexos das convenções em matéria processual no atos judiciais. In: CABRAL, Antonio do Passo, e NOGUEIRA, Pedro Henrique (coords.). Coleção grandes temas do novo CPC, v. 1 - negócios processuais. 2. ed. Salvador: JusPodivm, 2016, p. 303-329.

CÂMARA, Alexandre Freitas. O novo processo civil brasileiro. 2. ed. São Paulo: Atlas, 2016.

CRUZ E TUCCI, José Rogério. Natureza e objeto das convenções processuais. In: DIDIER JR., Fredie; CABRAL, Antonio do Passo; NOGUEIRA, Pedro Henrique (coords.). Coleção grandes temas do novo CPC, v. 1 - negócios processuais. 2. ed. Salvador: JusPodivm, 2016, p. 23-29.

CUNHA, Leonardo Carneiro. Negócios jurídicos processuais no processo civil brasileiro. In: DIDIER JR., Fredie; CABRAL, Antonio do Passo; NOGUEIRA, Pedro Henrique (coords.). Coleção grandes temas do novo CPC, v. 1 - negócios processuais. 2. ed. Salvador: JusPodivm, 2016, p. 39-72.

DI SPIRITO, Marco Paulo Denucci. Controle de formação e controle de conteúdo do negócio jurídico processual. Revista de Direito Privado, v. 63/2015, p. 125-193, jun./set. 2015. 
DIDIER JR., Fredie. Princípio do respeito ao autorregramento da vontade no processo civil. In: CABRAL, Antonio do Passo, e NOGUEIRA, Pedro Henrique (coords.). Coleção grandes temas do novo CPC, v. 1 - negócios processuais. 2. ed. Salvador: JusPodivm, 2016, p. 31-34.

Curso de direito processual civil: introdução ao direito processual civil, parte geral e processo de conhecimento. 17. ed. Salvador: JusPodivm, 2015, vol. I.

Fonte normativa da legitimação extraordinária no novo Código de Processo Civil: a legitimação extraordinária de origem negocial. Revista de Processo, São Paulo, RT, ano 39, v. 232, p. 69-76, jun. 2014. Disponível em:

<https://www.academia.edu/36514448/Fonte_normativa_da_legitima\%C3\%A7\%C3\%A3o_extraordi n\%C3\%A1ria_no_Novo_C\%C3\%B3digo_de_Processo_Civil_a_legitima\%C3\%A7\%C3\%A3o_extra ordin\%C3\%A1ria_de_origem_negocial>. Acesso em: 29 maio 2018.

GAJARDONI, Fernando da Fonseca. Teoria geral do processo: comentários ao CPC de 2015: parte geral [livro eletrônico]. São Paulo: Forense, 2015.

GRINOVER, Ada Pellegrini et al. Teoria geral do processo. 31. ed. São Paulo: Malheiros Editores, 2015.

LIPIANI, Júlia; SIQUEIRA, Marília. Negócios jurídicos processuais sobre a fase recursal. In: DIDIER JR., Fredie; CABRAL, Antonio do Passo; NOGUEIRA, Pedro Henrique (coords.). Coleção grandes temas do novo CPC, v. 1 - negócios processuais. 2. ed. Salvador: JusPodivm, 2016, p. 581613.

MAZZEI, Rodrigo; CHAGAS, Bárbara Seccato Ruis. Os negócios jurídicos processuais e a arbitragem. In: DIDIER JR., Fredie; CABRAL, Antonio do Passo; NOGUEIRA, Pedro Henrique (coords.). Coleção grandes temas do novo CPC, v. 1 - negócios processuais. 2. ed. Salvador: JusPodivm, 2016, p. 657-676.

NEVES, Daniel Amorim Assumção. Manual de direito processual civil [livro eletrônico]. 8. ed. Salvador: JusPodivm, 2016, vol. único.

NOGUEIRA, Pedro Henrique Pedrosa. Sobre os Acordos de Procedimento no Processo Civil Brasileiro. In: DIDIER JR., Fredie; CABRAL, Antonio do Passo; NOGUEIRA, Pedro Henrique (coords.). Coleção grandes temas do novo CPC, v. 1 - negócios processuais. 2. ed. Salvador: JusPodivm, 2016, p. 93-104.

OLIVEIRA, Paulo Mendes de. Negócios processuais e o duplo grau de jurisdição. In: DIDIER JR., Fredie; CABRAL, Antonio do Passo; NOGUEIRA, Pedro Henrique (coords.). Coleção grandes temas do novo CPC, v. 1 - negócios processuais. 2. ed. Salvador: JusPodivm, 2016, p. 555-578.

REALE, Miguel. Lições preliminares de direito. 27. ed. São Paulo : Saraiva, 2002.

REDONDO, Bruno Garcia. Negócios processuais: necessidade de rompimento radical com o sistema do CPC/73 para a adequada compreensão da inovação do CPC/2015. In: DIDIER JR., Fredie; CABRAL, Antonio do Passo; NOGUEIRA, Pedro Henrique (coords.). Coleção grandes temas do novo CPC, v. 1 - negócios processuais. 2. ed. Salvador: JusPodivm, 2016, p. 357-365. 
SÃO PAULO. Tribunal de Justiça de São Paulo. Agravo de Instrumento n. ${ }^{\circ} 22334788820178260000$. Relatora Maria Lúcia Pizzotti. São Paulo, 21 de março de 2018. Disponível em:

<https://esaj.tjsp.jus.br/cposg/open.do>. Acesso em: 04 abr. 2018.

Tribunal de Justiça de São Paulo. Agravo de Instrumento n. ${ }^{\circ}$ 2161535-45.2016.8.26.0000.

Relator Walter Cesar Exner. São Paulo, 19 de setembro de 2016. Disponível em:

$\langle$ https://esaj.tjsp.jus.br/cposg/open.do〉. Acesso em: 14 abr. 2018.

. Tribunal de Justiça de São Paulo. Agravo de Instrumento n. ${ }^{\circ}$ 2045753-87.2016.8.26.0000.

Relator Luis Fernando Nishi. São Paulo, 22 de setembro de 2016. Disponível em:

<https://esaj.tjsp.jus.br/cposg/open.do>. Acesso em: 14 abr. 2018.

. Tribunal de Justiça de São Paulo. Agravo de Instrumento n. ${ }^{\circ}$ 2118535-58.2017.8.26.0000.

Relator Paulo Pastore Filho. São Paulo, 30 de novembro de 2017. Disponível em:

<https://esaj.tjsp.jus.br/cposg/open.do〉. Acesso em: 14 abr. 2018.

WAMBIER, Luiz Rodrigues; TALAMINI, Eduardo. Curso avançado de processo civil: teoria geral do processo, v. 1. [livro eletrônico] 5. ed. São Paulo: Revista dos Tribunais, 2016.

YARSHELL, Flávio Luiz. Convenção das partes em matéria processual: rumo a uma nova Era?. In: DIDIER JR., Fredie; CABRAL, Antonio do Passo; NOGUEIRA, Pedro Henrique (coords.). Coleção grandes temas do novo CPC, v. 1 - negócios processuais. 2. ed. Salvador: JusPodivm, 2016, p. 75-92. 